1973

\title{
Justice Joseph Story, the Charles River Bridge Case and the Crisis of Republicanism
}

\author{
R. Kent Newmyer \\ University of Connecticut School of Law
}

Follow this and additional works at: https://opencommons.uconn.edu/law_papers

Part of the Judges Commons, Law and Politics Commons, and the Legal History Commons

\section{Recommended Citation}

Newmyer, R. Kent, "Justice Joseph Story, the Charles River Bridge Case and the Crisis of Republicanism" (1973). Faculty Articles and Papers. 73.

https://opencommons.uconn.edu/law_papers/73 


\section{HEINONLINE}

Citation: 17 Am. J. Legal Hist. 2321973

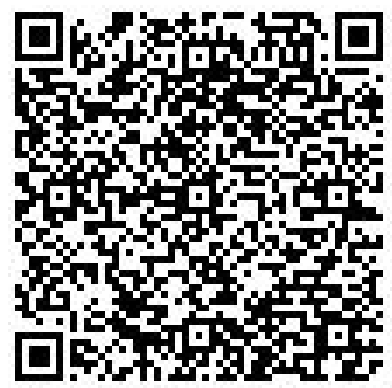

Content downloaded/printed from

HeinOnline (http://heinonline.org)

Mon Aug 15 18:16:31 2016

-- Your use of this HeinOnline PDF indicates your acceptance of HeinOnline's Terms and Conditions of the license agreement available at http://heinonline.org/HOL/License

-- The search text of this PDF is generated from uncorrected OCR text.

-- To obtain permission to use this article beyond the scope of your HeinOnline license, please use:

https://www.copyright.com/ccc/basicSearch.do?

\&operation $=$ go\&search Type $=0$

\&lastSearch $=$ simple\&all $=$ on\&titleOrStd $N o=0002-9319$ 


\section{Justice Joseph Story, The Charles River Bridge Case and the Crisis of Republicanism}

by KENT NEWMYER *

Justice Joseph Story's dissent in the Bridge Case pioneered no new law. Nor did it successfully reaffirm the old-although conservatives like Webster and Kent clung to it as legal gospel. Its importance has not been in law, then, but in legal history, where it has served as a benchmark from which historians have measured the distance and direction travelled by American law in the Age of Jackson.

The well-known question in the Bridge Case was whether the new free bridge encroached upon the allegedly exclusive toll rights of the earlier bridge, in violation of the contract clause of the Constitution, as interpreted in Dartmouth College v. Woodward. On this question the essential difference between Taney and Story, so most scholars argue, was over means, not ends:' Both, the argument goes, liked the corporation and assumed that the function of the law was to facilitate economic progress by releasing its productive energies. This could be done best, asserted Taney, by preventing existing corporations from holding back dynamic capital and technology by inferring monopoly claims from their charters; accordingly, he refused the old bridge company's claim. Story insisted that corporate expansion required a favorable environment for investment, which depended in turn on stable, predictable legislative charters, and accordingly he upheld the implied charter rights asked for by the Charles River Bridge Company.

The Chief Justice opted for "creative destruction," as one recent scholar put it, which is to say that he laid the unavoidable social costs of economic growth upon static capital. By supporting

*Department of History, University of Connecticut.

1. Stanley I. Kutler's Privilege and Creative Destruction: The Charles River Bridge Case (1971), is the most recent and the most persuasive book to make this point. Kutler uses the theory of Willard Hurst to explore the relationship of the Bridge case to economic expansion and makes no pretense at exploring the cultural dimensions of the case; nor does he undertake to analyze fully Story's dissent.

James McClellan's Joseph Story and the American Constitution: A Study in Political and Legal Thought with Selected Writings (1971), perceives, correctly, I believe, that the dispute between Story and Taney was cultural as well as legal. 
"privilege" Story made the public pay-either by foregoing a second bridge and continuing to pay tolls or by footing the bill for compensating the old bridge company under eminent domain. Taney's law was flexible, pragmatic, and instrumental-simultaneously accommodating the dynamic capital and state-based legislative democracy ushered in by the Jacksonians. Story's black letter tour de force comes off as impractical, inflexible, and nostalgic; Story as the "last of the old race of judges," grinding out "old law" to save vested property rights.

Insightful and useful though it is, this interpretation, especially as it concerns Story, is incomplete and in some important respects misleading. It is history written by the winners: the post1837 corporate boom is equated with progress, and Taney, post hoc ergo propter hoc, is given credit for it. Because Story differed from Taney, because he wrongly prophesied Taney's law would produce economic stagnation, his own legal position has been dismissed as backward-looking and unworkable. His dissent, in fact, appears more as a symbolic foil to the majority's opinion than a serious and possibly viable alternative to it.

The problem is to avoid anachronism, to take Story seriously, to reread his opinion with an open mind and to see the Bridge Case as he saw it-as part of a desperate struggle for the preservation of Republican society itself. ${ }^{2}$ To do so, I argue here, would show (1) that the legal debate between Story and Taney was more fundamental than is generally noted and that the difference between Taney in the Bridge Case and Marshall in the Dartmouth College Case was basically irreconcilable; (2) that Story and Taney differed on cultural objectives as well as legal means; (3) that Story's dissent was less inflexible, more workable, and less preoccupied with privilege and property and more with morality than is generally believed. In short, another look at Story's dissent might throw some light on his legal thinking, his place in American legal history, and at the same time illuminate something of the interrelation of law and cultural change in the early nineteenth century United States.

The Bridge Case for Story was part of an unmistakable pattern of disaster, which included the resurgence of political parties,

2. Robert E. Shalhope in his "Toward a Republican Synthesis: The Emergence of an Understanding of Republicanism in American Historiography," 29, William and Mary Quarterly (January, 1972), argues that Republicanism is basic to an understanding of American history in the early nineteenth century. My argument about the Bridge case explores a dimension of this thesis, and I hope helps to elaborate it. 
the election of Andrew Jackson, the rise of states' rights and nullification, the defeat of the Cherokees, the destruction of the Second Bank of the United States and national economic planning, the movement for codification of the common law, the death of Marshall and the emergence of the Jacksonian Court. Economic expansion was the issue in the Bridge Case, to be sure, but more fundamentally it raised the question of who should make and maintain the rules of republican society. By what system was the course of American history to be guided? As Story put it, while listening to arguments of counsel, "The only question here is of sheer power."3

The power struggle which Story saw, I contend, was between law and politics-a a struggle which originated in the ambiguities and tensions within Republicanism itself. The original and fundamental principle of Republican political theory was sovereignty of the people, but what the Framers gave to the people with one hand they took back with the other, for the corollary to popular sovereignty was the axiom that law, not men, governed. ${ }^{4}$ The American people were sovereign but they could speak in their sovereign capacity only in organic convention and had spoken only in their Constitution. Beneath this supreme law, permeating and informing it, was the common law, which the newly-constituted states made the foundation of their respective jurisdictions. Law, then, and the system of courts designed to administer and maintain it, provided the basic framework of public and private action-one designed, first, to maximize the individual energies unleashed by the Revolution (and both the Constitution and the common law took on this promotive function), and second, to prevent the abuse of public power by both the magistrates and the people.

No sooner had the Republican system been instituted than the conflict between popular sovereignty and rule of law began to manifest itself. Political party was the catalyst: By fusing factions into a national majority, party organization subverted Madison's principle that the size of the American republic would prevent majority tyranny. Party could be effectively used to harmonize the executive and congress, thus short-circuiting the constitutional system of checks and balances. Nor could noblesse oblige be counted on to preserve rule of law because party undercut the system of deference by substituting service to party organization for proven

3. [Judge Story's] Memorandums of Arguments in the Supreme Court of the United States beginning with the Jan [uar] y Term 1831 and ending with the Jan [uar] y Term 1832, p. 4. Ms in Treasure Room, Harvard Law School Library.

4. My analysis of Republicanism, though not my emphasis, has depended heavily on Gordon Wood, Creation of the American Republic (1969). 
social status as the test of leadership. And the same erosive effects were visible on the state as well as national level. With democracy let loose, the whole system of rule by law seemed in jeopardy. The people seemed bent on claiming and using their sovereignty. One by one the barriers fell: Congress, where parties originated, was the first to go- the Senate proved no more resistant than the House. State government, already parochial in outlook and mediocre in talent, was debilitated further by party influence. The presidency, rather than rising above party, as the Framers planned, had, by the time of Jackson, become the prize of party and the nerve center of its operations. The basic Republican principle that the sovereign people spoke only in constitutional convention was forgotten as the new breed of professional politicians claimed sovereignty for themselves by virtue of their election. Republicanism succumbed to democracy, law to politics.

But not quite. Congress, the presidency, noblesse oblige were gone, to be sure, but the Court remained. Under Marshall it had become the final arbiter and guardian of the American legal system. Only it could bring the people back to their Republican senses and restore the system of law which kept republican citizens moral and virtuous. Or so Justice Story and other conservatives desperately hoped-which brings us to the Charles River Bridge Case.

If indeed the Bridge Case reflected a crisis of Republicanism, as I argue, that fact should be apparent in the legal debate between Story and Taney. The argument could not be merely a debate over how best to facilitate corporate growth, nor could it, so far as Story is concerned, be simply a question of securing property rights. Careful scrutiny of Story's dissent, in fact, shows that the disagreement was about fundamentals - about basic legal issues, about the role of the law and the Court in the social-political order-in short, about law and history.

What appeared on the surface to be a dispute between Story and Taney over legal rules was in fact a profound disagreement over law. Although the case was constitutional, both agreed that the common law should resolve the issue whether the Charles River Bridge charter by implication conveyed the exclusive right to collect tolls. But beyond this they disagreed sharply. Taney's interpretation of the charter rested on the common law of royal grants. Story turned to the law of contract. Before he did, however, he met the Chief Justice on his own ground (a fact which worked to disguise the deep chasm separating their legal positions). The weakness of Taney's analysis of the law of royal grants, Story argued, 
was that he took "a single insulated position" as a "general axiom." Traversing the whole field of authorities which Taney ignored, Story concluded that Taney's rule of law - that in doubtful cases the benefit goes to the King and against the adventurers-was "exclusively confined to cases of mere donation, flowing from the bounty of the crown." When the grant turned upon valuable consideration, Taney's rule ceases and "the grant is expounded exactly as it would be in the case of a private grant-favorable to the grantee."'

Story's scholarly dispute with Taney over authorities is significant in itself, as I hope to show later, but what must be emphasized, what Story took pains to emphasize, was that he differed with Taney's entire legal frame of reference. The crucial point was, he declared emphatically, that a bridge charter was "not the case of a royal grant" and consequently "the rules of common law in relation to royal grants have, therefore, in reality, nothing to do with the case." Rather, "we are construing a grant of a legislature, which though in the form of a statute, is still but a solemn contract." It followed that the majority's arguments about axioms of strict construction, their theories of public welfare which turned on the analogy of a charter to a royal grant were out-of-bounds.

By resting his argument on private contract, Story raised a different set of questions and established different ground rules for their resolution. The legal confrontation was not between the state and the individual, not between ruler and subject (as in the royal grant analogy), but between contracting parties of equal authority. The problem, therefore, was not to define special prerogatives belonging to the state but to determine what two contracting parties (presumed to be equal in their capacity to negotiate and honorable in their intentions) meant by their agreement: what was given and what taken. On this question Story had no trouble in showing that inferential reasoning was no extraordinary concession demanded by the counsel for the old bridge but a necessary and legitimate common law tool of interpretation. As Oliver Wendell Holmes put it in his discussion of contract in The Common Law, "The very office of construction is to work out, from what is expressly said and done, what would have been said with regard to events not definitely before the minds of the parties, if these events had been considered." Common reason, good sense, embodied in common law axioms of construction, guided the inqury into intent.

5. Charles River Bridge v. Warren Bridge 11 Peters 420, 589 (1837).

6. Charles River Bridge v. Warren Bridge 11 Peters $420,597$.

7. Charles River Bridge v. Warren Bridge 11 Peters 420, 598.

8. Charles River Bridge v. Warren Bridge 11 Peters 420, 603.

9. The Common Law, 237 (1963). Also see 244, 245-46, 251-52, 261. 
Given his premise that private contract law governed the case, Story's argument is all but irresistible. Mutuality of interest existed, a meeting of minds and an exchange for consideration had taken place: The legislature wanted a bridge built across the Charles; the bridge company wanted to make a profit. For building the bridge, keeping it in repair, and giving it to the state after forty years (later extended to seventy), the legislature granted the company the right to collect tolls. The contingency "not definitely before the minds of the parties" was whether the toll right was exclusive to the extent that it prohibited the legislature from chartering an adjacent toll-free bridge. Story put it to the common law and to "the common sense of every man." Would any sensible business man, he asked, venture capital in a risky enterprise (which bridging the Charles in 1785 was), in which the sole profit was the right to collect tolls, if the legislature reserved the right to destroy those tolls at any time by chartering an adjacent free bridge? ${ }^{10}$ Even without explicitly saying so, the legislature recognized the company's exclusive right to take tolls, Story argued, because it was equipped with the same common sense that the businessmen had and because, in the eyes of the law, it was presumed to have bargained in good faith. Any doubt about the legislature's intent to grant exclusive tolls was removed by the compensation awarded to Harvard for destroying its ferry rights by chartering the Charles River Bridge and by the thirty-year extension of the original charter to the old Bridge Company as compensation for chartering another bridge across the Charles in 1792 which might have diminished the old company's tolls. And when the exclusive right was given, "the law giveth, impliedly, whatever is necessary for the taking and enjoying the same."

Story's argument not only follows Dartmouth College but lays bare the radical implications of that decision. Not merely were grants and charters within the meaning of Article I, Section 10 of the Constitution, but they were to be interpreted according to private law. Taney and the majority refused to be bound by this logic. They did not overrule Dartmouth College, to be sure, but neither did they merely refuse to extend it by implication. By talking royal grants instead of private contract, Taney's opinion simply ignored Dartmouth College altogether-which is what Story perceived.

\section{III}

He also perceived with even greater distress that Taney's refusal to apply the rigorous logic of contract undercut the moral foundations of Republicanism. For no other area of law in the nine-

10. Charles River Bridge v. Warren Bridge 11 Peters 420 at 608-609. 
teenth century was so laden with cultural baggage, none so congenial to Republican society, as was contract. ${ }^{11}$ As Western and American society moved from corporateness to individualism, as the model of the new American man changed from a passive, delimited, class bound one to a rational, self-sufficient creature of volition, contract emerged as the necessary basis of social order. The movement of history in the eighteenth and nineteenth centuries was, in fact, as Sir Henry Maine aptly phrased it, from status to contract.

By the contract device, American Puritans established their individual and collective relationship to their God and bound themselves together in churches and civil communities. From religion, the colonial experience, the English legal heritage, and the influence of John Locke, contract entered into the fabric of Republican political thought. To be sure, Republicanism emphasized individual responsibility to a greater whole, and the principles of popular sovereignty and representative government somewhat undercut the contractual relationship between the rulers and the people. But contract was made to justify the Revolution itself and it was the Lockean theory of social contract that best explained how a nation of free, rational, individual men could form itself into the collective sovereign people. What was true politically was equally true economically. As the American people moved progressively toward laissez faire capitalism, contract emerged as that area of law central to economic expansion. As such it was-along with provisions against retrospective legislation, which is in fact part of contract in the broadest sense-guaranteed by the Constitution itself. When Marshall applied the law of private contract to governmental economic activities, then he was merely following the syntactic imperative of culture to integrate and harmonize:12 private law became public law; common law infused constitutional law; private morality became synonymous with public, republican morality.

It was this permeating morality of contract which Story aimed to preserve in his Bridge dissent (and both he and Kent used the word "moral" to describe the contract issue). By shifting from contract to royal grant, Taney subtly but surely effected a shift in

11. Willard Hurst noted that "the years 1800-1875 were . . above all else years of contract in our law." Law and Conditions of Freedom in the Nineteenth Century United States 18. See Wood, Creation of the American Republic, $282,288,289$, for reference to contract in the thinking of the framers of the Constitution.

12. Gerald Garvey, Constitutional Bricolage (1971) has some fine insights on the integration of American law and culture, on what he calls the buyer-seller mode of social organization. 
cultural values from a social order based on a buyer-seller modelwhere the individual was the basic unit of social organization, where contract was the means of collective action, and moral standards and legal ones, too, were internal and individualizedto the ruler-subject model which introduced a notion of public good outside and beyond individuals, one subject to state determination.

Story's repudiation of this cultural shift was explicit. He did not deny that the legislature could enter into the individualistic, laissez faire economic process, indeed assumed that it would do so to stimulate individual activity and thus promote public welfare (as when it chartered the Charles River Bridge Company). But once the legislature entered the economic arena through grants and charters, it was governed by the same laws as applied to individuals - that is, by private contract law. "Our legislatures neither have, nor affect to have, any royal prerogatives," declared Story, referring to Taney's mistaken analogy of a legislative charter to a royal grant. Indeed, the Massachusetts legislature has no claim to sovereignty whatsoever. Only the people are sovereign, he continued-applying the Federalist constitutional theory of 1787 to the states - and the people in their sovereign capacity speak only in their constitutions. "What solid ground is there to say [then], that the words of a grant, in the mouth of a citizen, shall mean one thing, and in the mouth of the legislature shall mean another thing?"13 In short, public welfare was not some external value which a sovereign legislature could call on when it pleased to control the economic process. Public economic good was the collective product of individual effort and of contractual relationships between individuals (under which category Story put both the state legislatures and the business corporations). There was no disjunction between mercantilism and free enterprise. One morality governed all - or with the help of the law might be made to do so. What Story wanted to achieve through law was not just economic expansion, as some historians have assumed, but economic expansion and the preservation of Republican morality. Indeed, in his dire forecast about the effect of Taney's opinion, he went the final step to argue that only with such morality could progress be achieved.

History disproved Story's proposition that contractual morality as he laid it out in his dissent was the sine qua non of corporate expansion. But what about his formula for a moral economic growth, i.e., economic expansion that would not undercut the basic principle of private contract? Two arguments against its viability need to be considered briefly: first, that Story's legal formula for

13. Charles River Bridge v. Warren Bridge, 11 Peters 420 at 602. 
morality worked only against the legislature and not the corporation, and, second, that it would not work at all.

Concerning the allegation that Story's morality was mainly a device for obscuring his pro-corporate, private property bias: Assuredly, Story worked through the law (public and private) to make the corporation an effective vehicle for capitalist expansion. Nor can it be denied that he viewed state legislatures as obstacles to corporate growth. But it did not follow that he wanted an unregulated corporation, one free from the constraints of Republican morality. After all, it was Story's concurrence in Dartmouth College that recognized the right of state legislatures to reserve, in their charters, the power to regulate corporations-providing only that the reservation clause was explicit, so that the corporation could accept or reject legislative terms. In Story's scheme, however, it was not the legislature but the courts, working especially in the realm of private contract law, that would mainly hold corporations to their moral duties. Using much the same reasoning he applied against the legislature in the Bridge Case-that is, by using the rational, fair-minded, practical individual as the rule-giving model-Story worked to enlarge corporate duties and responsibilities. In Bank of Columbia v. Patterson's Administrator (1813), ${ }^{14}$ the Judge departed from existing authorities to make corporations liable for contracts not under corporate seal made by their authorized agents. His Bank of the United States $v$. Dandridge opinion $(1827)^{15}$ extended that principle to cover obligations entered into by cashiers of banking corporations. In effect both cases established contractual duties by construction and implication, by the same reasoning, in short, that would guide Story in the Bridge Case. $\mathrm{He}$ also worked to hold corporations to a strict performance of contracts made with private parties as in his pioneering opinion in Mumma v. The Potomac Company (1834), ${ }^{16}$ which announced the doctrine that a corporation's contract survives its dissolution and that the capital stock of dissolved corporations becomes a trust fund for the satisfaction of debts against the corporation. Story also accepted the doctrine emerging in state courts of corporate liability for torts, and he knew and counted on the traditional common law writ of mandamus and the doctrine of ultra vires as remedies against corporations that exceeded their charter rights or failed to perform duties imposed upon them. In short, Story made the same Republican assumptions about corporations that he made about individuals and legislatures - that law, especially

14. 7 Cranch 299 (1813).

15. 12 Wheaton 64 (1827).

16. 8 Peters 281 (1834). 
law administered by the courts, could make them responsible and moral.

Now what about the argument that Story's dissent would not have worked at all-that it would have forestalled corporate expansion by fortifying existing corporations with monopoly protection? It cannot be denied that Story's ruling would have worked to slow down and restrain corporate growth; and in a real sense that was his intention. But it does not follow that his dissent precluded considerable economic advancement. Even in the area of most obvious applicability - that of bridges-Story's opinion offered no absolute monopoly protection to existing corporations. First, an implied grant of exclusive rights, even if successfully claimed, would last only for the period of time set by legislative discretion. (For example, the Charles River Bridge would have reverted to the state in 1855.) And if existing charters were subject to monopolistic interpretations, future ones could explicitly deny such interpretations if the legislature so willed. Nor did Story's ruling preclude the building of other bridges even during the period of the grant and such bridges had, in fact, been built across the Charles. Whether existing bridges could claim monopoly rights against new bridges depended on the extent to which a second bridge damaged the revenue of existing bridges, which was necessarily a question of degree-a question, in short, for future courts to decide on new facts. Story made clear, both in his manuscript notes on the arguments and in his opinion, that the Court's decision was limited strictly to the case at hand and was "not to decide the principles for all cases. . . ." 17 His ruling put no dead hand on future courts.

If Story's concession to the old bridge company did not rule out new bridges, then how can historians be so certain that it would have unreasonably curtailed the growth of railroad corporations? The fact that existing canal and turnpike companies tried to stop railroads by arguing implied monopoly does not prove the point. It is one thing to argue that a charter to a canal corporation would by implication preclude parallel canals (for the duration of the grant), quite another that such a charter would automatically preclude parallel railroads. The important point is that future courts could distinguish between a canal and a railroad in such matters as function and termini, and Story's contention about the limited scope of the Bridge ruling would invite them to do so. Certainly the touchstones of common sense and business acumen by which the common law presumed to read the mind of contracting parties would not apply so irresistibly as in the Bridge Case. And perhaps

17. [Judge Story's] Memorandums of Arguments, op. cit. supra note 3 , at p. 161 . 
most importantly, legislatures could and surely would make sure in future charters to guarantee against implied monopoly in areas of new technology.

The argument is speculative of necessity, but the idea that Story saw and provided for controlled economic growth is certainly consistent with the promotive thrust of his entire legal system. At the very least, doesn't he deserve a "Scotch verdict" on the question of workability?

\section{IV}

Story's dissent reveals much about his system of law and about the role he designed for the Court (which follows logically from his system). The law which Story fashioned to save the Republic from the onslaught of democracy in the Bridge dissent was neither moral and idealistic, scientific and rational, nor pragmatic and instrumental-it was all of these together. And it was, I suggest, the same ingredients fashioned in the same organic manner that constitute Story's larger system of law as revealed in his remarkable and varied legal career as judge, scholar, and teacher.

Certainly no lawyer of the age save Kent was so committed to making law technically, scientifically pure. Witness his teaching at Harvard Law School, his series of commentaries on various branches of the law, his popular articles in encyclopedias, law journals, and general periodicals, and especially his scholarly opinions (and more especially his opinions on circuit), ${ }^{18}$ which were designed to educate as much as to decide the controversies. But legal science was not an end in itself. The first lesson Story learned from his tutor Sam Sewall, ${ }^{19}$ the same he saw practiced in the court of Chief Justice Theophilus Parsons, was that inherited legal principles, even from the superb Blackstone, were imperfect and incomplete and would have to be shaped and molded to fit the special needs of the American people. As judge and jurist, he made scholarship walk in the street, the marketplace, and the counting house. While he started his legal inquiries with black letter, he was also guided by the usages of commerce and business with which he was intimately acquainted. And for all his respect for inherited principles, he never hesitated to depart from or go beyond them if practical necessity required-as in his conception of public and private corporations, ${ }^{20}$ his doctrine of the contractual responsibil-

18. Kent Newmyer, "Justice Joseph Story on Circuit and a Neglected Phase of American Legal History," 14 American Journal of Legal History (April, 1970), 125-26.

19. Samuel Sewall to Story, Philadelphia, February 12, 1799. Story Papers. Clements Library. University of Michigan.

20. See his concurrence in Dartmouth College v. Woodward, 4 Wheaton 518 at 666,669 (1819). 
ities of corporate agents, or the binding nature of parole contracts. It was this very same practical, creative legal scientist who argued strenuously that Christianity was a part of the common law, ${ }^{21}$ who, of all judges of the period, revered and retained natural law notions of the eternal, unchanging and moral principles of jurisprudence.

Story never got his system entirely together, unfortunately never analyzed it or philosophized about it, never resolved the tensions within it which came from his effort to fuse so many divergent ingredients. Story the lawyer was like a geographer and map maker. He looked idealistically to the day when the whole of God's creation would be explored and mapped out with scientific rules and precise predictable relationships so that human action might be rational, equitable and productive. But he knew in fact that the job was not done, that old maps would have to be modified and new areas charted. Law was both substance and process; fixed rules and the science of modifying and making them; map making and the final map; science and mystery.

If Republican law was so complex and so delicate, and if legal science was so demanding, it followed that lawyers and judges, not professional politicians and legislators, should be entrusted with the main duty of law-keeping and law-making. And herein lay Story's final argument with Taney in the Bridge Case, for the Chief Justice conceded too much authority to the legislature and professional politicians who then ruled there. By arguing that there was some principle of public welfare beyond the operation of the buyerseller contractual process and by conceding that the legislature had some special prerogative to voice that principle, Taney came dangerously close to the ultimate democratic heresy-the very one presumably stamped out by Republican constitutional theory-that the legislature itself and not the people was sovereign.

But even more troubling to Story than Taney's concession to legislative power was his demonstrated incompetence in the Bridge opinion to exercise the responsibilities that Story would have given to the Court. It was a matter of scholarship. That Taney should misread the authorities on royal grants was one thing, but not to consult them was another, and to misconstrue the entire legal framework of the case was even worse. Taney was either cynical or incompetent; though Story did not say so, it is a good guess that he agreed with Webster that Taney's performance, however "plausible," was ultimately "cunning and jesuitical." But whether cynical or inept, the result was disastrous, for by abandoning the rational

21. James McClellan, Joseph Story and the American Constitution (1971), pp. 118-159. 
system of scientific inquiry and the struggle for objectivity, the Court launched itself on a turbulent sea of judicial subjectivism. Without scholarship and legal science, political opinion would take over. Rather than controlling politics and party, Taney and the majority now invited them into the temple. Tragic enough it would have been had the Court gone to defeat doing its moral duty (as in the Cherokee Indian Case), but to surrender without battle was ignominy. The old Republic seemed lost.

$\mathrm{V}$

Story's position in the 1830's was remarkably analogous to Jonathan Edwards' in the Great Awakening in that both attempted to maintain the unity and coherence of an earlier social system which was disintegrating under the impact of rapid historical change. Edwards wanted to preserve Puritanism as a way of life: Story aimed to save Republicanism. For Edwards, society's salvation lay in the permeating spirit of true religion; for Story in true law. Story's system of law like Edwards' theology was organic and synthetic like the culture it hoped to conserve - that is to say, it reached out to integrate politics, economics, and other aspects of society into a harmonious and moral community.

Story's undertaking was conservative in the largest sense (perhaps American conservatism comes of age with him). But it does not follow that his legal system was static or retrogressive. Natural law assumptions of the eighteenth century permeated his legal thinking, to be sure, but he harmonized them, as Blackstone did earlier, with rational, systematic legal science. And to this fusion of morality and science he added a pragmatic instrumentalism quite alien to the eighteenth century common law-a pragmatism which was designed to bring law into harmony with the unique demands of American history. His own protestations to the contrary nonwithstanding, Story was not "the last of the old race of judges" but was a transitional figure who was simultaneously a rationalist and a romantic idealist, a conservative and an innovator, who at a particularly fertile moment in American history tried to fashion an American jurisprudence. His system of law, the parts of which never quite coalesced, is not so much an indication to legal historians of what American law was, as a creative vision of what it might have been.

Antebellum law-of which Taney's Bridge opinion was an intimation-moved away from Story's organic model: Instrumentalism broke the moral confines Story attempted to impose and American law took its character more and more, as Willard Hurst shows, from the chaotic forces of economic expansion. A new model of the law of economic growth responsive to new technology and 
mature capital replaced the old commercial one designed to promote investment by securing it absolutely. ${ }^{22}$ Natural law thinking fell into the background where it served to legitimize the new law (and not incidentally to obscure the realities of legal development and retard the rise of a self-conscious jurisprudence). At the same time, law-making initiative began to shift from the Court (to which Story had entrusted his delicately balanced system) to the legislature, where the new forces of instrumentalism operated with less hindrance and restraint. Story's model lawyer-statesman-a moral and virtuous natural aristocrat who mastered all branches of law, knew the real world, and devoted himself to polite learning and public service-gave way to legal specialists and lawyer-politicians.

To be sure, bits and pieces of Story's system would be incorporated into the main stream of American law. His arguments would bolster future judicial conservatives in their battle against legislative dominance. But his system, the legal cosmology he fashioned to save the old Republic, would become a relic of history, a curiosity on Clio's junkpile. But still history's losers deserve their day even if only to show the complex process by which the victors carried the field-and possibly to show the price paid for their victory.

22. I would like to thank Professor Morton Horwitz of Harvard Law School for giving me his insights on this point. 